\title{
ОЦІНКА ПОКАЗНИКІВ ЕФЕКТИВНОСТІ РЕДУКЦІЙНО-ОХОЛОДЖУВАЛЬНИХ УСТАНОВОК, ПРАЦЮЮЧИХ НА БАЗІ РІЗНИХ ДЖЕРЕЛ ТЕПЛОПОСТАЧАННЯ ПРОМИСЛОВИХ ПІДПРИМСТВ
}

У статті проведена оцінка показників ефективності редукційно-охолоджувальних установок, працюючих на базі різних джерел теплопостачання промислових підприємств. Головними показниками ефективності визначено тиск та температуру пари на виході з установки. У результаті проведеного дослідження теплова потужність системи коливалася у межах від 37,32 MBт до 48,82 MBт, температурний діапазон пари на виході з РОУ склав 265-280 ㄷ, тиск пари на виході з РОУ тримався в межах 22-22,8 кгс/см².

Ключові слова: редукційно-охолоджувальна установка, теплопостачання, промислове підприємство.

O.YA. VOLOSHANUK, O.V. NECHIPORENKO Cherkasy State Technological University

\section{EVALUATION OF EFFICIENCY INDICATORS OF REDUCTION AND COOLING INSTALLATIONS WORKING ON THE BASIS OF DIFFERENT HEAT SUPPLIES OF INDUSTRIAL SUPPLY SUPPLIES}

The article evaluates the efficiency of reduction and cooling units operating on the basis of various sources of heat supply of industrial enterprises. The main efficiency indicators are the pressure and temperature of steam at the outlet of the install ation. As a result of the study, the thermal capacity of the system ranged from $37.32 \mathrm{MW}$ to $48.82 \mathrm{MW}$, the temperature range of steam at the outlet of the ROU was $265-280 \mathrm{oC}$, the steam pressure at the outlet of the ROU was in the range of $22-22.8 \mathrm{kgf} / \mathrm{cm}^{2}$.

Key words: reduction-cooling installation, heat supply, industrial enterprise.

\section{Вступ}

В даний час, в умовах економічної нестабільності та кризи, спаду виробництва, зростання цін на природне паливо, гостро постає питання економії енергоресурсів, оптимізації виробництва і вдосконалення технологічного процесу. За останні роки, характерною особливістю енергетики України стало різке зниження споживання енергоресурсів промисловими підприємствами, що призводить до зниження економічних та експлуатаційних показників всіх ланок теплоенергетичної системи промислових підприємств. Особливо серйозною проблемою у швидкоплинній ціновій політиці держави на енергоресурси $\epsilon$ утворення деяких перекосів у внутрішньогалузевому ціноутворенні при визначенні вартості енергоресурсів, що виробляються. Тому, для покриття необхідного промислового навантаження використовують передбачені тепловою схемою і зазвичай призначені для аварійного або резервного покриття частини цього навантаження постійно-діючі редукційно-охолоджувальні установки. При роботі редукційно-охолоджувальних установок (РОУ) безповоротно «зникає» потенціал теплоносія. Крім того, деякі надлишки вторинного газу (доменний, коксовий та ін.) на промисловому підприємстві можна направити на отримання теплової енергії для покриття теплофікаційних навантажень на опалення і гаряче водопостачання, у зв'язку 3 гострою необхідністю створення на ринку енергоресурсів більш конкурентоспроможної продукції у вигляді гарячої води для теплових мереж. Основними частинами системи теплоенергопостачання промислових підприємств є: 1) підприємства, що виробляють необхідні види енергоресурсів (ЕР); 2) системи транспорту і розподілу ЕР між споживачами (теплові та електричні мережі); 3) споживачі енергетичних ресурсів.

Розрізняють два види теплопостачання - централізоване і децентралізоване. При централізованому теплопостачанні джерело теплопостачання ТЕЦ, АТЕЦ або котельня розташовані на значній відстані від самого віддаленого споживача теплоти, зазвичай рівному від декількох до десяти кілометрів. В цьому випадку необхідно спорудження теплової мережі, що забезпечує доставку теплоносія до споживача. В якості теплоносія для систем центрального опалення житлових будинків і гарячого водопостачання (ГВП) зазвичай використовується вода. При температурах теплоносія $100-150{ }^{\circ} \mathrm{C}$ вода застосовується і в різних технологічних промислових процесах. При температурах теплоносія понад $150{ }^{\circ} \mathrm{C}$ в промисловості частіше використовують пар.

На території України отримали однакове поширення два способи відпустки тепла з водяної теплової мережі - закритий і відкритий. Закритий спосіб використовується при жорсткій місцевій воді, відкритий при м'якій. При закритому способі вода з теплової мережі не забирає, а нагріває в теплообмінниках холодну водопровідну воду. В цьому випадку мережева вода практично повністю, за винятком витоків, повертається 3 теплової мережі в джерело теплопостачання, де знову відбувається їі нагрів і повернення в теплову мережу. При відкритому способі відпустки теплоти вода для ГВП або технологічних потреб забирається 3 теплової мережі і після використання зливається у каналізацію.

У парових системах теплопостачання зазвичай використовується насичена або слабо перегріта пара. Це дозволяє забезпечити в процесі конденсації пари практично постійну температуру в технологічній зоні робочого процесу. Пара подається паропроводом. Конденсат, що утворюється в теплообмінних пристроях, 
збирається в конденсатозбірниках i потім транспортується по конденсатопроводу до джерела теплопостачання. Якщо конденсат виявляється забрудненим, то він зливається у каналізацію.

Розподіл джерел виробітки теплової енергії на промисловому підприємстві з урахуванням показників ефективності редукційно-охолоджувальної установки дозволило б зменшити економічні втрати за рахунок максимального використання енергоресурсів і вирішити проблему з недоліком потужностей в теплопостачанні промислових підприємств.

Саме тому, оцінка показників ефективності редукційно-охолоджувальних установок працюючих на базі різних джерел теплопостачання промислових підприємств, стає все більш важливою і актуальною.

\section{Аналіз літературних даних і постановка проблеми}

Сучасні дослідження редукційно-охолоджувальних установок працюючих на базі різних джерел теплопостачання доводять не аби який інтерес вчених до зазначеної теми. Проблеми підвищення ефективності використання паливно-енергетичних ресурсів шляхом енергозбереження розкрито В. А. Маляренко, О. Л. Шубенко, С. Ю. Андрєєвим, М. Ю. Бабаком та О. В. Сенецьким [1]. Авторами виконано аналіз стану й потенціалу розвитку світової та базової енергетики України. Показано, що значні резерви містяться у «малій» енергетиці, яка є головним споживачем паливно-енергетичних ресурсів.

Детальний аналіз теплових схем ТЕС, особливості та вимоги до розташування ТЕС, а також проблеми, що виникають при перетворенні енергії при експлуатації ТЕС розкрив Ю. О. Гічов [2].

Ф.І. Лухтура, А.В. Пижиков, О.А. Хлестова [3] дослідили шляхи підвищення теплової ефективності та надійності промислової ТЕЦ. Отримані результати можуть використовуватися для оцінки та моніторингу доцільності впровадження парових турбін малої потужності в системах теплопостачання промислових об'єктів і комунальних господарств.

Моделювання АСР температури пару за редукційно-охолоджувальною установкою енергоблоку AEC на базі технологічної ділянки редукційно-охолоджувальної установки, що входить у другий контур енергоблоку АЕС здійснили В. О. Терлецький та Г. П. Лисюк [4]. Науковцями розроблена автоматизована система регулювання температури за редукційно-охолоджувальною установкою, в якій управління РОУ здійснюється за допомогою цифрового ПІ-регулятора.

Також варто відмітити роботи таких науковців, як Л. В. Високих, В. В. Клименко та В. І. Кравченко [5], В. А. Маляренко, О. Л. Шубенко, С. Ю. Андрєєв, М. Ю. Бабак, О. В. Сенецький [1], В.В. Клименко, В. I. Кравченко, Р. В. Телюта [6], T. Maurer [7], S. X. Li, J. S. Wang [8], M. N. Chepyrniy, N. V. Rezydent [9], A. Emadi [10].

Однак, незважаючи на масштабність наукових досліджень, можна говорити про те, що наукових робіт, які б максимально повно розглядали показники ефективності редукційно-охолоджувальних установок працюючих на базі різних джерел теплопостачання промислових підприємств з урахуванням специфіки та особливостей, на даний момент немає.

Об'скт, мета та завдання дослідження

Об'єкт дослідження - редукційно-охолоджувальна установка.

Мета дослідження - оцінка показників ефективності редукційно-охолоджувальних установок працюючих на базі різних джерел теплопостачання промислових підприємств. Для досягнення поставленої мети, у рамках статті, необхідно вирішити наступні завдання:

1) Розкрити принципи формування системи теплопостачання з залежності від виду теплоносія.

2) Навести умовні схеми систем теплопостачання в залежності від обладнання, що використовується. Детально описати принцип роботи кожної схеми.

3) Запропонувати методологію розрахунку показників ефективності роботи редукційноохолоджувальної установки у рамках системи теплопостачання.

4) Розрахувати показники ефективності роботи редукційно-охолоджувальної установки у рамках системи теплопостачання.

5) Здійснити аналіз результатів ефективності редукційно-охолоджувальних установок та провести оцінку точності розрахунку.

Матеріали та методи досліджень ключових показників ефективності редукційноохолоджувальних установок працюючих на базі різних джерел теплопостачання промислових підприємств

В роботі використані матеріали 3 наявного досвіду в реалізації теплопостачання промислових підприємств, а також розглянута специфіка застосування редукційно-охолоджувальних установок на базі різних систем теплопостачання, здійснено оцінку ключових показників ефективності редукційноохолоджувальних установок. В роботі використані наступні методи досліджень: аналіз, узагальнення, систематизація, побудова аналогій і синтез наявних даних.

Формування системи теплопостачання в залежності від виду теплоносія. Система теплопостачання повинна забезпечувати споживача потрібною кількістю теплоти необхідної якості (тобто теплоносієм необхідних параметрів). У децентралізованих системах джерело тепла і споживачі знаходяться так близько, що перенесення теплоти йде без використання теплової мережі. Децентралізовані системи поділяються на [11]: 


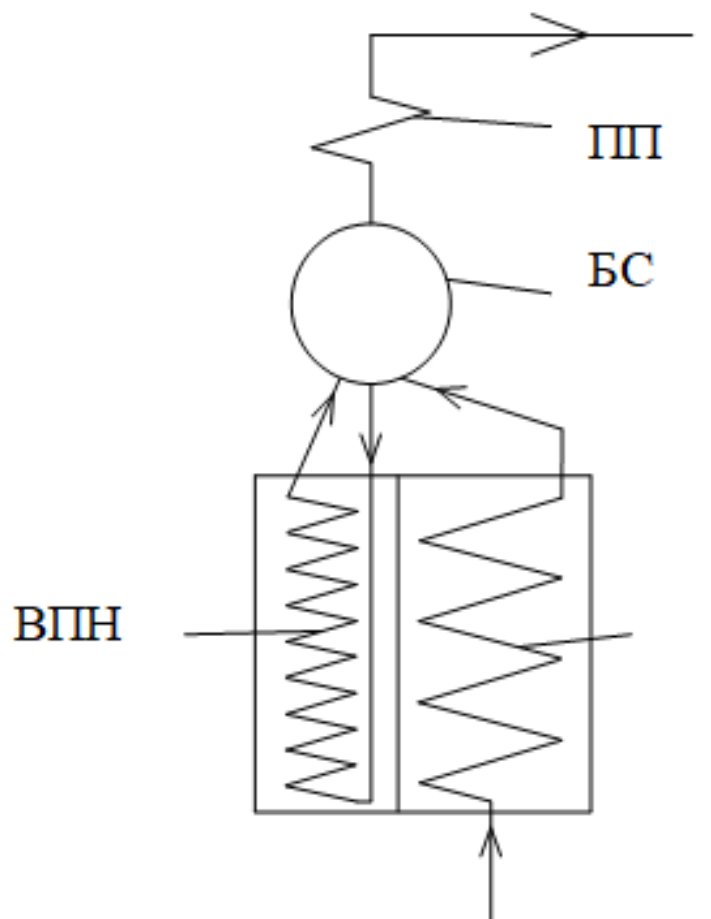

ПП - перегрівач пари; ВПН - випарювальні поверхні нагріву; БС - барабан-сепаратор; ЕМ - економайзер

Рис. 1. Умовна схема парового котла у рамках системи теплопостачання

індивідуальні (в кожному

приміщенні своє джерело теплоти - пічне, квартирне опалення);

- місцеві (від місцевої або індивідуальної котельні - центральне опалення).

У системах централізованого теплопостачання джерело теплоти i споживачі тепла так відокремлені, що перенесення теплоти відбувається за спеціальними тепловими мережами. Централізоване теплопостачання ділиться на групове (група будівель), районне (кілька груп будівель - житловий район), міське (кілька районів) та міжміське (кілька міст від одного джерела). Комплекс установок i обладнання

для

підготовки

теплоносія

на джерелі

(поглинанн

я теплоти),

транспорту

вання i

розподілу

теплоносія

(теплова

мережа) і використання теплоносія у споживачів (віддача теплоти) це система централізованого теплопостачання. Відповідно до виду теплоносія системи теплопостачання поділяють на парові, водні та пароводні. На формування дієвої системи теплопостачання здійснює вплив тип встановлених в котельні котлів і параметри теплоносія, що виробляється котлами, а також вид і параметри теплоносія, який необхідний кінцевому споживачеві [12]. Котли встановлені в котельні передбачено парові (рис. 1) або водні (рис. 2).

Призначення редукційно-охолоджувальної установки - зниження параметрів пари за рахунок дроселювання і охолодження іiі водою, введеною в охолоджувач пари у розпорошеному стані [13]. Розрізняють декілька видів РОУ: а) підвищеного і низького тисків; б) високого тиску; в) розпалювальні РОУ. Подача охолоджуючої води в РОУ виробничих котелень зазвичай здійснюється з магістралі живильної води після деаератора. Схема РОУ представлена на рис. 3.

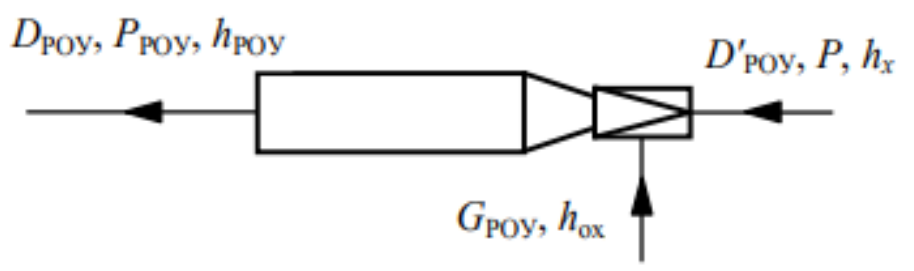

Рис. 3. Схема редукційно-охолоджувальної установки

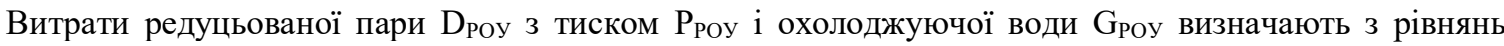
теплового і матеріального балансів РОУ:

$$
\begin{aligned}
& D_{P O Y}^{\prime} h_{x}+G_{P O Y} h_{O x}=D_{P O Y} h_{P O Y} \\
& D_{P O Y}^{\prime}+G_{P O Y}=D_{P O Y}
\end{aligned}
$$

Вирішуючи спільно рівняння (1) і (2), отримаємо

$$
G_{P O Y}=\frac{D_{P O Y}^{\prime}\left(h_{x}-h_{P O Y}\right)}{h_{P O Y}-h_{o x}}
$$

Тут $D_{P O y}^{\prime}$ - витрата гострої пари при тиску $P$ і ступеню сухості $x$, кг/с; $h_{x}=h^{\prime \prime}-(1-x) r-$ ентальпія гострої пари, кДж/кг; $h^{\prime \prime}$ - ентальпія сухої насиченої пари при тиску $P$, кДж/кг; $r-$ теплота 
пароутворення води у котлі при тиску $P$, кДж/кг; $h_{P O y}-$ ентальпія скороченої пари, кДж/кг; $h_{o x}-$ ентальпія охолоджуючої води, що надходить в РОУ, кДж/кг.

Умовна схема редукційно-охолоджувальної установки у рамках системи теплопостачання наведена на рис. 4.

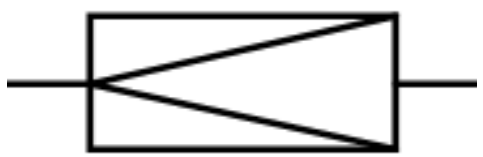

Рис. 4. Умовна схема редукційно-охолоджувальної установки у рамках системи теплопостачання

Парова система теплопостачання. Паровий котел виступає головним об'єктом, який здійснює нагрівання води до виділення пари. Пара $з$ парового котла через редукційно-охолоджувальну установку направляється, за допомогою паропроводу, до споживача. Конденсат використаної у споживача пари, повертається в котельню, через конденсатопровід, та надходить в деаератор, який служить для видалення 3 живильної води розчинених у ній газів i, в першу чергу, кисню повітря. Втрати конденсату компенсуються очищеною водою, яка також подається в деаератор. Очищення води здійснюється у очищувачі води, що компенсує втрати конденсату. Суміш конденсату і додаткової очищеної води після деаерації направляється в котел в якості живильної води. Умовна схема парової системи теплопостачання наведена на рис. 5.

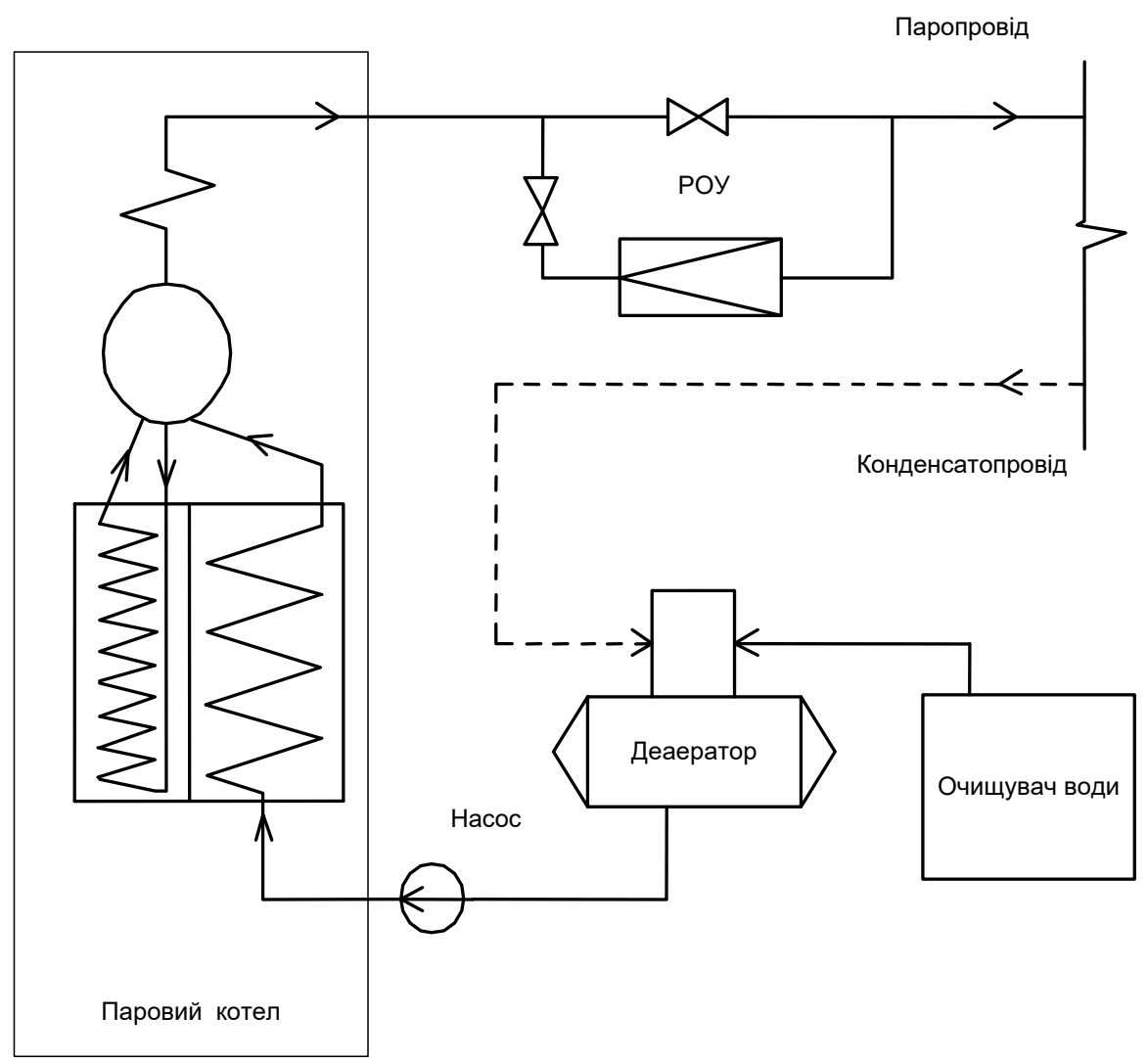

Рис. 5. Умовна схема парової системи теплопостачання 3 паровим котлом

Водяна система теплопостачання. Вода з мережі, використана у споживачів, після підживлення i підвищення тиску в мережевому насосі, який призначений для підвищення тиску води 3 мережі 3 метою подолання опору мережевих підігрівачів, теплової мережі та забезпечення тиску нагрітої води 3 мережі відповідно до вимог споживачів надходить, в підігрівачі. Інтенсивність підживлення залежить від ступеня відхилення тиску води в мережі у зворотній лінії від номінального значення.

Пара $з$ парового котла через редукційно-охолоджувальну установку направляється в мережеві підігрівачі (поверхневі пароводяні теплообмінники), де нагріває воду і конденсується. Конденсат відводиться в деаератор, який служить для видалення з живильної води розчинених у ній газів і, в першу чергу, кисню повітря. 


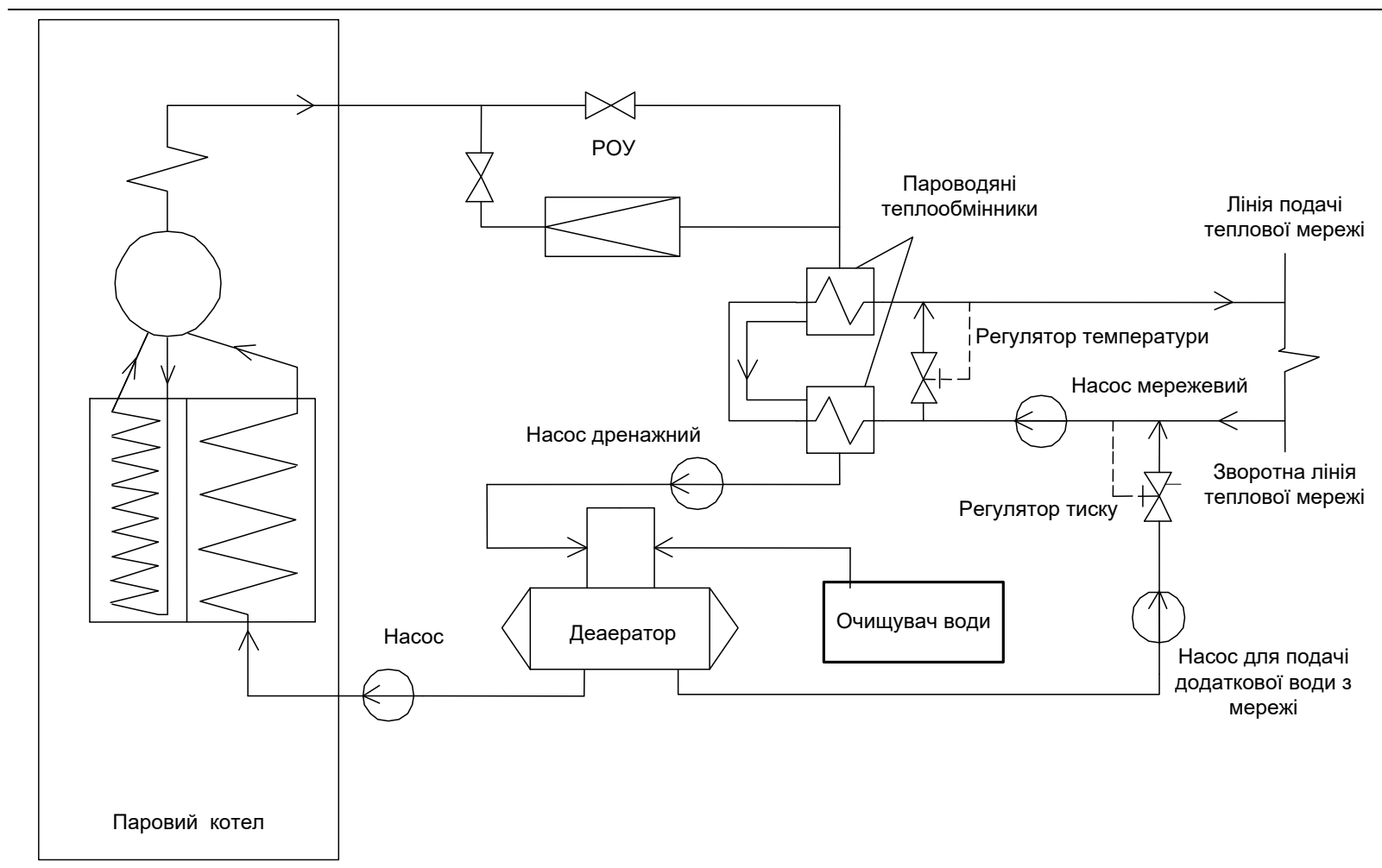

Рис. 6. Умовна схема водяної системи теплопостачання з паровим котлом

Регулювання температури води 3 мережі, що надходить на лінію подачі теплової мережі, здійснюється в бік зниження шляхом подачі води зі зворотної лінії теплової мережі. Втрати конденсату і води 3 мережі компенсуються додатковою очищеною водою, що надходить 3 очищувача води.

Пароводяна система теплопостачання. По суті, це об'єднання парової та водяної систем теплопостачання. Умовна схема пароводяної системи теплопостачання з паровим котлом наведена на рис. 7.

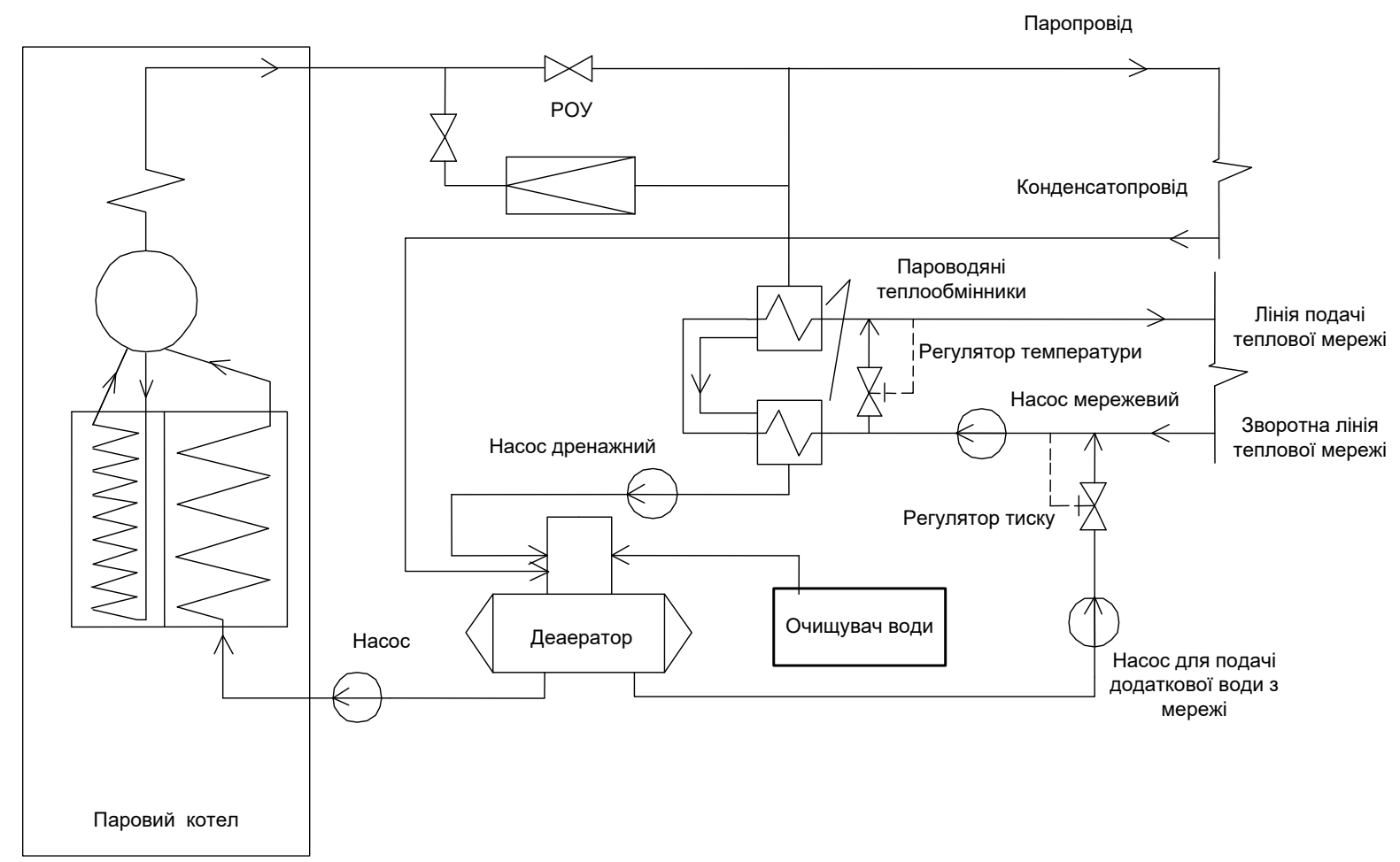

Рис. 7. Умовна схема пароводяної системи теплопостачання з паровим котлом

Комбінована система теплопостачання. Однією $з$ дієвих систем теплопостачання є система 3 підігрівом води з мережі у середині барабану котла. Умовна схема пароводяної системи теплопостачання 3 паро водогрійним котлом наведена на рис. 8. Вбудований у барабан котла підігрівач мережевої води являє собою теплообмінник змішувального типу.

Вода 3 мережі надходить у барабан котла через стабілізуючий короб у порожнину розподільного 
короба, який має перфороване ступеневе днище. Перфорація забезпечує струменеву подачу води назустріч пароводяної суміші, що надходить з випарних поверхонь нагріву котла, що сприяє нагріванню води.

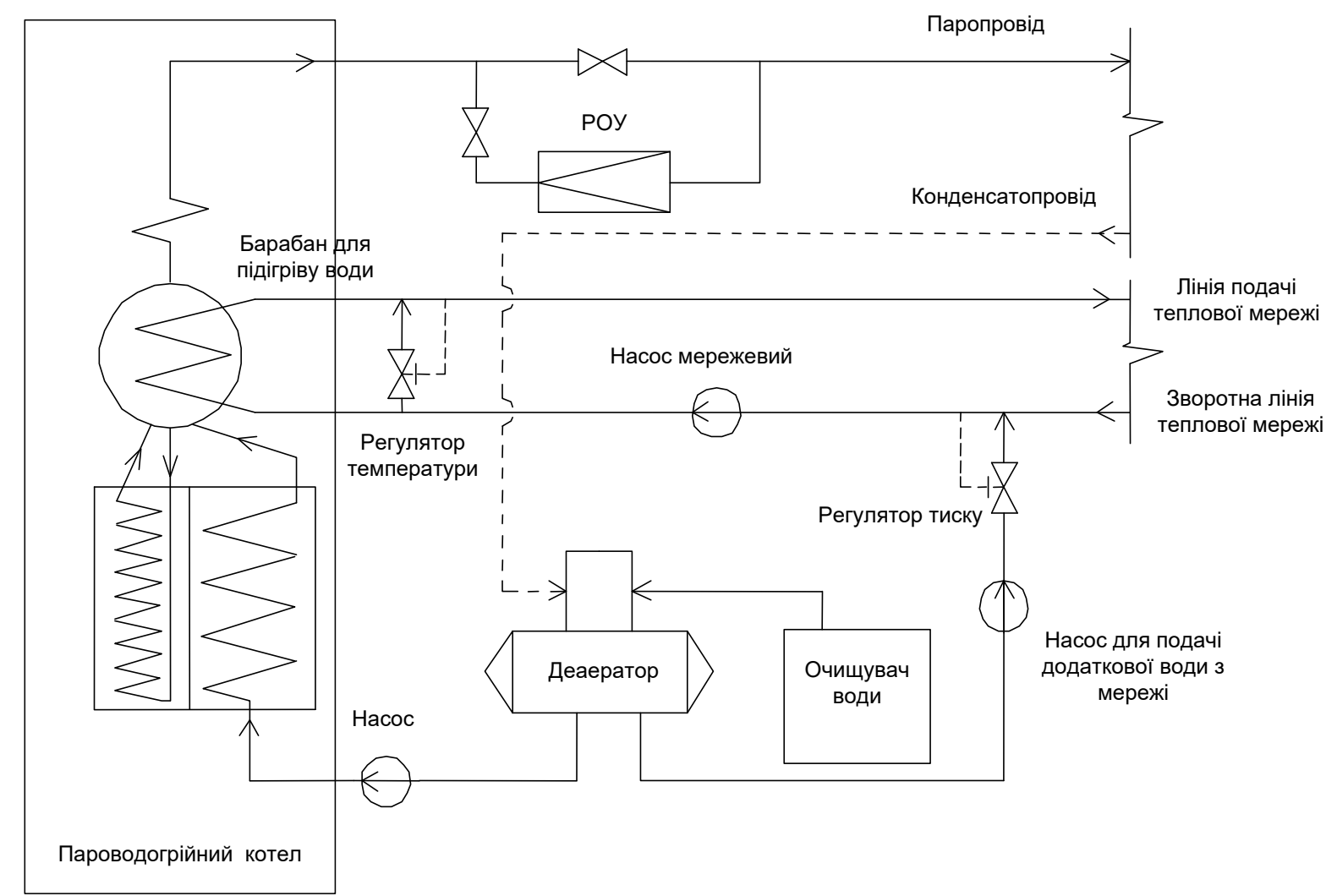

Рис. 8. Умовна схема пароводяної системи теплопостачання з паро водогрійним котлом та вбудованим барабаном для нагріву води

Загальна продуктивність котла системи теплопостачання у своєму складі має два основних показника: теплота пари та теплота нагрітої води з мережі. Математична складова теплопродуктивності котла має вигляд:

$$
Q_{k}=M_{c}\left(i_{2}-i_{1}\right)+D_{n}\left(i_{n}-i_{ж в}\right)
$$

де

$M_{c}$ - витрата води з мережі, що нагрівається;

$i_{1}, i_{2}$ - ентальпія води до нагрівання та після нагрівання відповідно;

$D_{n}$ - продуктивність котла у системі теплопостачання;

$i_{n}, i_{ж в}-$ ентальпія пари та ентальпія живильної води відповідно.

Здійснимо перетворення (4), щоб визначити витрату води з мережі, що нагрівається, отримаємо:

$$
M_{c}=\frac{Q_{k}-D_{n}\left(i_{n}-i_{\text {ж⿻ }}\right)}{i_{2}-i_{1}}
$$

Отримане рівняння (5) показує, що показник витрати води з мережі, що нагрівається та теплопродуктивність котла, що входить у систему теплопостачання взаємозалежні. Так при постійній складовій теплопродуктивності котла та при поступовому збільшенні кількості виробленої пари, зменшується витрата води з мережі, а у разі зменшення кількості виробленої пари збільшується витрата води $з$ мережі.

У разі заміни барабану для нагріву води, на поверхні нагріву, у газохід котла вбудовуються відповідні пластини, які слугують елементами нагріву. Умовна схема пароводяної системи теплопостачання 3 паро водогрійним котлом та вбудованими поверхнями наведена на рис. 9.

Поверхневий теплообмінник для нагріву води встановлюється у корпус котла, поруч 3 економайзером.

Методологія розрахунку. У якості варіантів розрахунку були обрані умови режимів роботи обладнання ТЕЦ, що відповідають квазістаціонарним режимам. Ці умови визначені для постійних значень відпуску кількісно-якісних параметрів тепла на виробничі та опалювальні потреби у часовому проміжку, що перевищує характерний час теплової інерційності контуру.

Виробничі параметри взяті (за величинами та розмірностями) з виробничої документації. Розрахунок якісних параметрів і показників відпуску теплової енергії з котлів (РОУ) проведений в системі СІ. 


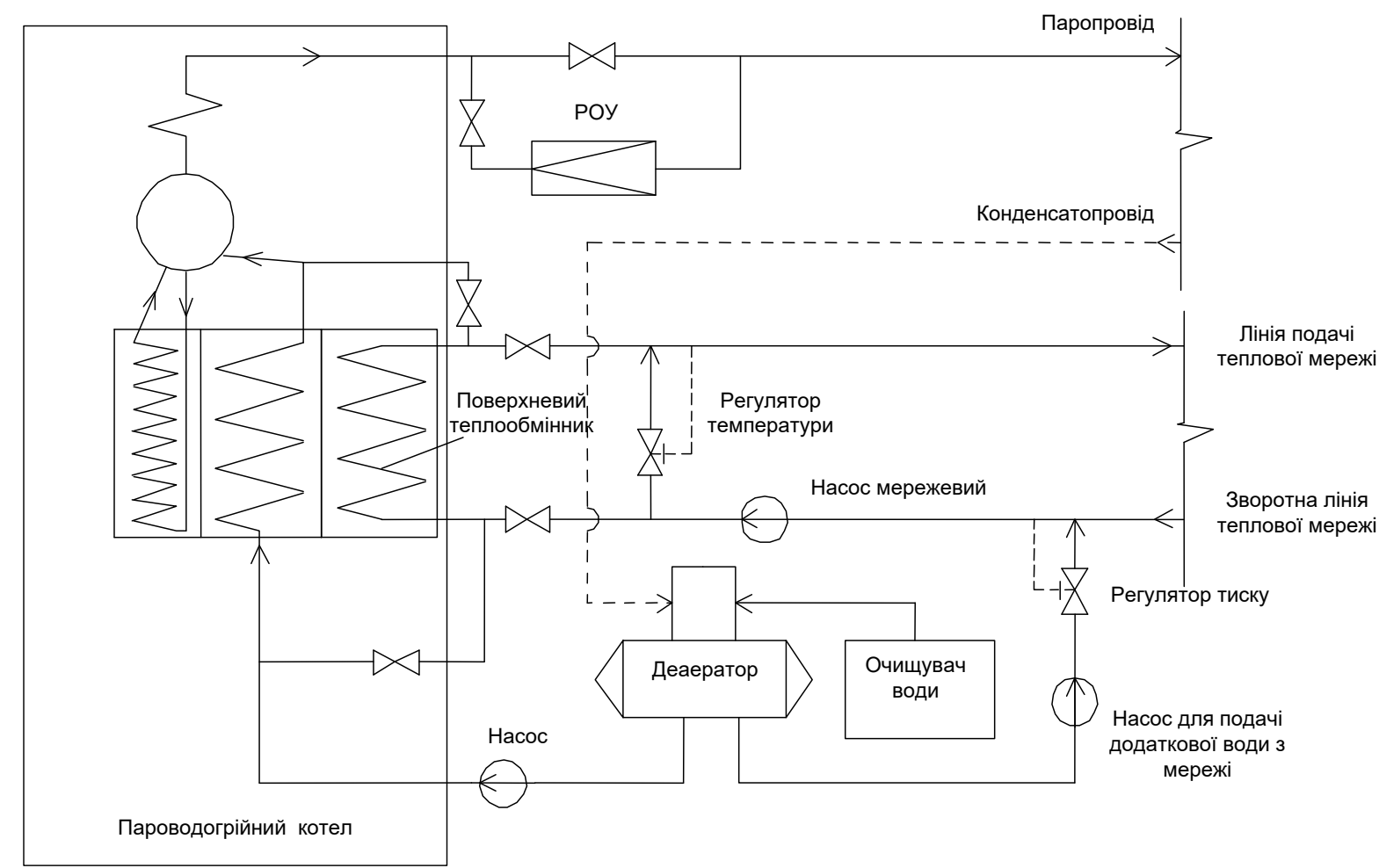

Рис. 9. Умовна схема пароводяної системи теплопостачання 3 паро водогрійним котлом та вбудованим поверхневим теплообмінником для нагріву води вигляді:

Розрахункові формули для визначення показників режиму роботи обладнання представляються у

а) Теплова потужність промислового відбору, МВт:

$$
Q_{n}=D_{n} \cdot h_{n} / 3600
$$

де

$D_{n}$ - витрата виробничої пари, т/год;

$h_{n}$ - ентальпія виробничої пари, кДж/кг.

б) Теплова потужність теплофікаційного відбору, МВт:

$$
Q_{r}=G_{M B} C_{P}\left(t_{n M}-t_{o M}\right) / 3600
$$

$G_{M B}$ - витрата води з мережі через мережевий підігрівач, т/год;

$t_{n м}$ - температура води, яка надходить у мережу, ${ }^{\circ} \mathrm{C}$;

$t_{\text {ом }}$ - температура води, що повертається з мережі, ${ }^{\circ} \mathrm{C}$;

$C_{P}-$ теплоємність води, кДж/ кг * ${ }^{\circ} \mathrm{C}$.

в) Теплова потужність тепла, що відпускається у паропровід власних потреб 0,12 МПа, МВт

$$
Q_{\text {кол } 1,2}=G_{H \Pi} C_{p} \Delta \bar{t}_{O B}+G_{B B} C_{p} \Delta \bar{t}_{B \Pi B}+G_{C B} C_{p} \Delta \bar{t}_{C B}
$$

де

$G_{H \Pi}-$ неповернення конденсату, т/год;

$G_{B B}$ - витрата водопровідної води через ПВВ, т/год;

$G_{C B}$ - витрата сирої води через ПСВ, т/год;

$\Delta \bar{t}_{O B}-$ нагрів очищеної води у деаераторі додаткової води $1,2 \mathrm{aтa},{ }^{\circ} \mathrm{C}$;

$\Delta \bar{t}_{\text {ВПв }}$ - нагрівання водопровідної води в ПВПВ, ${ }^{\circ} \mathrm{C}$;

$\Delta \bar{t}_{C B}-$ нагрівання сирої води в ПСВ, ${ }^{\circ} \mathrm{C}$;

г) Теплова потужність по пару перед РОУ, МВт:

$$
Q_{o}^{P O Y}=D_{o}^{P O Y}\left(h_{o}^{P O Y}-h_{B}^{P O y}\right) / 3600
$$

$D_{o}^{P O У}$ - витрата пари перед РОУ (після котла), т/год;

$h_{o}^{P O У}$ - ентальпія пари перед РОУ (після котла), кДж/кг; 
$h_{в}^{P O У}-$ ентальпія живильної води перед котлом, кДж/кг.

д) Поправочні коефіцієнти на зміну параметрів пари у проточній частини системи від входу до точки відбору К1 (промисловий відбір), К2 (верхній опалювальний відбір), К3 (нижній опалювальний відбір) визначаються за формулою:

$$
K_{j}=\frac{1-T_{K} / \gamma \cdot T_{\text {вiдб }}}{1-T_{K} / T_{0}}
$$

Результати досліджень ключових показників ефективності редукційно-охолоджувальних установок працюючих на базі різних джерел теплопостачання промислових підприсмств

Визначення показників витрат. На підставі розрахованих параметрів і показників варіантів режимів генерації тепла (таблиця 1) здійснюємо розрахунок витрати палива відповідно до запропонованої методики визначення енергетичної ефективності.

Результати розрахунку для різних варіантів досліджуваних режимів наведені в таблиці 2

Дані про фактичні витрати палива за досліджувані періоди часу взяті з показань приладу обліку по витраті споживання газу на ТЕЦ.

Достовірність показань комерційного приладу обліку споживання газу на ТЕЦ підтверджується його високим класом точності - 0,002.

Таблиця 1

Дані по РОУ

\begin{tabular}{|c|c|c|c|c|c|c|c|c|c|c|c|c|c|}
\hline \multirow{2}{*}{ № } & \multirow{2}{*}{$\begin{array}{c}\text { Найменування } \\
\text { показника }\end{array}$} & \multirow{2}{*}{ Позн. } & \multirow{2}{*}{$\begin{array}{c}\text { Одиниці } \\
\text { виміру }\end{array}$} & \multicolumn{10}{|c|}{ Варіант виміру } \\
\hline & & & & 1 & 2 & 3 & 4 & 5 & 6 & 7 & 8 & 9 & 10 \\
\hline 1 & $\begin{array}{c}\text { Витрата пари } \\
\text { після РОУ }\end{array}$ & $G_{n P O Y}$ & т/год & 0 & 60 & 65 & 75 & 75 & 75 & 75 & 75 & 75 & 75 \\
\hline 2 & $\begin{array}{l}\text { Тиск пари } \\
\text { після РОУ }\end{array}$ & $p_{n P O Y}$ & 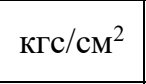 & 22,8 & 22,8 & 22,8 & 22 & 22 & 22 & 22 & 22 & 22 & 22 \\
\hline 3 & $\begin{array}{c}\text { Температура } \\
\text { пари після } \\
\text { РОУ } \\
\end{array}$ & $t_{n P O Y}$ & ${ }^{\circ} \mathrm{C}$ & 265 & 265 & 265 & 280 & 280 & 255 & 270 & 270 & 265 & 270 \\
\hline 4 & $\begin{array}{c}\text { Тиск пари } \\
\text { перед РОУ }\end{array}$ & $p_{0 P O Y}$ & кгс $/ \mathrm{cm}^{3}$ & 127 & 127 & 127 & 127 & 127 & 127 & 127 & 127 & 127 & 127 \\
\hline 5 & $\begin{array}{c}\text { Температура } \\
\text { пари перед } \\
\text { РОУ }\end{array}$ & $t_{0 P O Y}$ & ${ }^{2} \mathrm{C}$ & 535 & 535 & 535 & 535 & 535 & 535 & 535 & 535 & 535 & 535 \\
\hline 6 & \begin{tabular}{|c|} 
Температура \\
живильної \\
води на вході \\
у РОУ \\
\end{tabular} & $t_{B P O Y}$ & ${ }^{3} \mathrm{C}$ & 165 & 165 & 165 & 165 & 165 & 165 & 165 & 165 & 165 & 165 \\
\hline 7 & $\begin{array}{c}\text { Ентальпія } \\
\text { пари після } \\
\text { РОУ }\end{array}$ & $h_{n P O Y}$ & кДж/кг & 2945 & 2945 & 2945 & 2955 & 2955 & 2905 & 2950 & 2950 & 2940 & 2950 \\
\hline 8 & $\begin{array}{c}\text { Ентальпія } \\
\text { пари після } \\
\text { котла } \\
\end{array}$ & $h_{0 P O Y}$ & кДж/кг & 3435 & 3435 & 3435 & 3435 & 3435 & 3435 & 3435 & 3435 & 3435 & 3435 \\
\hline 9 & $\begin{array}{c}\text { Ентальпія } \\
\text { живильної } \\
\text { води перед } \\
\text { РОУ } \\
\end{array}$ & $h_{B P O Y}$ & кДж/кг & 669 & 669 & 669 & 669 & 669 & 669 & 669 & 669 & 669 & 669 \\
\hline 10 & $\begin{array}{c}\text { Температура } \\
\text { живильної } \\
\text { води перед } \\
\text { котлом } \\
\end{array}$ & $t_{\varkappa в}$ & ${ }^{3} \mathrm{C}$ & 235 & 235 & 235 & 235 & 235 & 235 & 235 & 235 & 235 & 235 \\
\hline 11 & $\begin{array}{c}\text { Калорійність } \\
\text { газу } \\
\end{array}$ & $Q_{н р}$ & кДж/м ${ }^{3}$ & 33656 & 33656 & 33656 & 33656 & 33656 & 33656 & 33656 & 33656 & 33656 & 33656 \\
\hline 12 & ККД котла & $\eta_{\text {нг }}$ & & 0,94 & 0,94 & 0,94 & 0,935 & 0,935 & 0,935 & 0,935 & 0,935 & 0,935 & 0,935 \\
\hline 13 & $\begin{array}{c}\text { ККД } \\
\text { трубопроводів } \\
\end{array}$ & $\eta_{m p}$ & & 0,97 & 0,97 & 0,97 & 0,966 & 0,966 & 0,966 & 0,966 & 0,966 & 0,966 & 0,966 \\
\hline
\end{tabular}


Результати розрахунку

\begin{tabular}{|c|c|c|c|c|c|c|c|c|c|c|c|c|c|}
\hline \multirow{2}{*}{ № } & \multirow{2}{*}{$\begin{array}{l}\text { Найменування } \\
\text { показника }\end{array}$} & \multirow{2}{*}{ Позн. } & \multirow{2}{*}{$\begin{array}{l}\text { Одиниці } \\
\text { виміру }\end{array}$} & \multicolumn{10}{|c|}{ Варіант виміру } \\
\hline & & & & 1 & 2 & 3 & 4 & 5 & 6 & \begin{tabular}{|l|}
7 \\
\end{tabular} & 8 & 9 & 10 \\
\hline 1 & $\begin{array}{c}\text { Витрата пари } \\
\text { на РОУ }\end{array}$ & $G_{\text {oPOY }}$ & т/год & 0 & 53,81 & 58,32 & 67,42 & 67,42 & 66,31 & 67,02 & 67,02 & 66,58 & 67,02 \\
\hline 2 & $\begin{array}{c}\text { Теплова } \\
\text { потужність } \\
\text { пари перед } \\
\text { РОУ }\end{array}$ & $Q_{O P O Y}$ & $\mathrm{MBT}$ & 0 & 37,32 & 40,1 & 46,3 & 46,3 & 45,87 & 46,82 & 46,82 & 46,510 & 46,82 \\
\hline 3 & $\begin{array}{c}\text { Витрата } \\
\text { палива на } \\
\text { РОУ }\end{array}$ & $G_{2 P O Y}$ & $\mathrm{HM}^{3} / \mathrm{c}$ & 0 & 1,21 & 1,32 & 1,53 & 1,53 & 1,51 & 1,53 & 1,53 & 1,52 & 1,53 \\
\hline
\end{tabular}

Аналіз результатів ефективності редукційно-охолоджувальних установок та оцінка точності розрахунку. Із отриманих значень витрати палива та значень ефективності спрацювання РОУ, відхилення показників знаходяться у межах від 0,3 до 1,5\%. Відхилення близько 1,5\% можна пов'язати зі збільшенням характерного часу теплової інерційності контуру по зовнішнім умовам заповнення втрат циклу 3 неповерненням конденсату, а також часу стабілізації ККД парового котла.

Розрахунок середньозваженого значення, дисперсії і середньоквадратичного відхилення величини здійснюємо відповідно до формул математичної статистики. Результати розрахунку даних параметрів наведені в таблиці 3.

Таблиця 3

Результати оцінки похибки отриманих значень

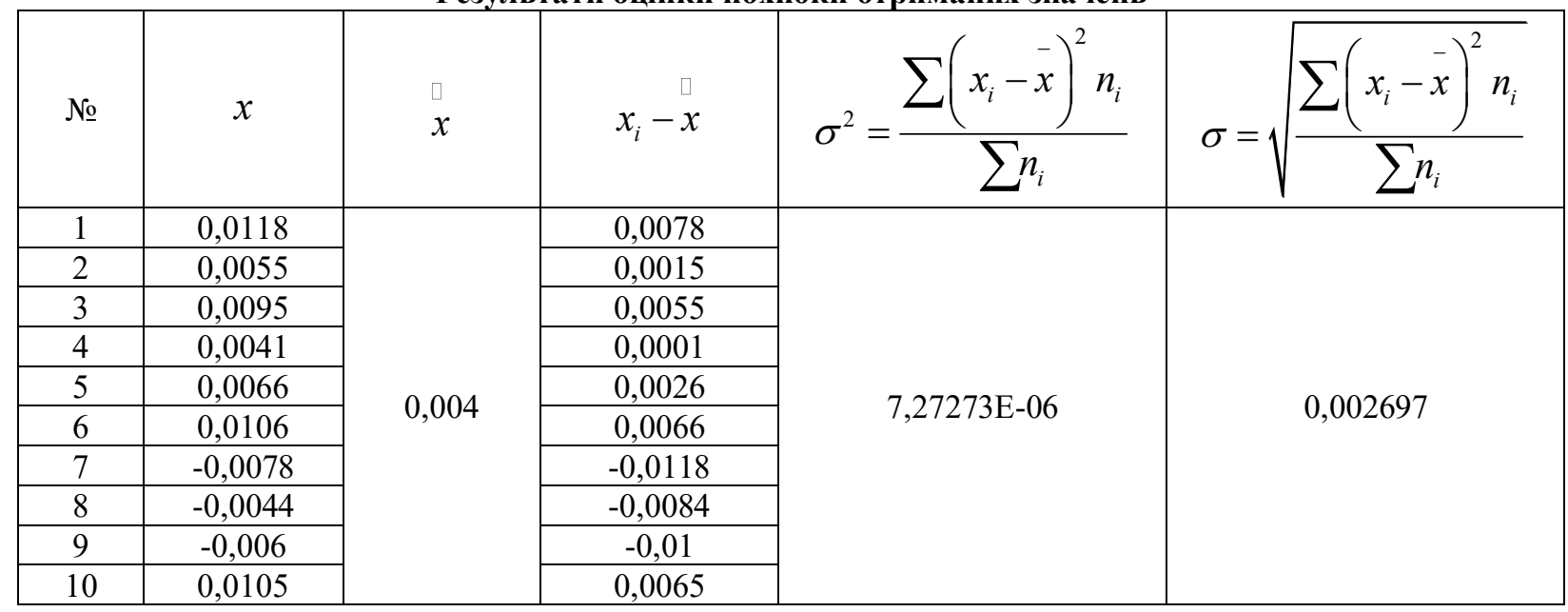

На підставі результатів оцінки похибки розрахунку робимо висновок, що похибка розрахунку становить $(0,4+0,2697) \%$.

На підставі отриманих результатів обробки експерименту можна констатувати працездатність запропонованої методики визначення ефективності редукційно-охолоджувальної установки і можливість подальшого іiі використання для вирішення задач оптимального формування системи теплопостачання промислових підприємств.

Обговорення результатів дослідження ключових показників ефективності редукційноохолоджувальних установок працюючих на базі різних джерел теплопостачання промислових підприемств

Основним показником ефективності роботи редукційно-охолоджувальної установки є температура $\mathrm{i}$ тиск пари після установки. Ці показники є найбільш впливовими на дієвість всієї системи теплопостачання, однак, як було зазначено вище, одержуваний конденсат на виході збільшує надійність роботи основного устаткування теплової схеми. Для підвищення теплової економічності системи доцільно ввести попередній підігрів живильної води на вході в редукційно-охолоджувальну установку.

Варто відзначити, що в процесі роботи станції теплопостачання може виникати необхідність зупинки постійно діючих РОУ, а значить і зупинки всієї системи, що є досить трудомістким процесом i негативно позначається на експлуатаційних характеристиках останньої.

Висновки

Розвиток редукційно-охолоджувальних установок дозволить в майбутньому більш ефективно використовувати теплову енергію пари. Зараз стоїть завдання по модифікації вже існуючого обладнання 3 метою зниження витрат на його виробництво, підвищення його довговічності і економічної ефективності. 
На основі проведеного в статті аналізу і досліджень можна зробити наступні висновки:

1. Принципи формування системи теплопостачання в залежності від виду теплоносія грунтуються на загальних показниках якості. Система повинна бути оснащена теплоносієм необхідних параметрів та здійснювати мінімальні енерговитрати за умови повного задоволення потреб кінцевого споживання.

2. Систем теплопостачання в залежності від обладнання, що використовується поділяють на парові, водні та пароводні. Призначення редукційно-охолоджувальної установки - зниження параметрів пари за рахунок дроселювання і охолодження ії водою, введеною в охолоджувач пари у розпорошеному стані. У разі застосування парової системи паровий котел виступає головним об'єктом, який здійснює нагрівання води до виділення пари. Пара 3 парового котла через редукційно-охолоджувальну установку направляється, за допомогою паропроводу, до споживача. Водяна система працює за принципом постійного надходження пари з парового котла через редукційно-охолоджувальну установку у мережеві підігрівачі, де нагрівається і конденсується вода. Змішана - пароводяна система працює з урахуванням обох систем теплопостачання, які працюють в тандемі.

3. Методологія розрахунку показників ефективності роботи редукційно-охолоджувальної установки у рамках системи теплопостачання, грунтується на визначенні теплової потужності тепла та пари, витратах пари та палива.

4. Показник витрат води 3 мережі, що нагрівається та теплопродуктивність котла, що входить у систему теплопостачання взаємозалежні. Отримані показники роботи редукційно-охолоджувальної установки у рамках системи теплопостачання показали стабільну динаміку збільшення витрати палива на РОУ. Теплова потужність системи коливалася у межах від 37,32 МВт до 48,82 МВт. Температурний діапазон пари на виході з РОУ склав $265-280{ }^{\circ} \mathrm{C}$. Тиск пари на виході з РОУ тримався в межах $22-22,8$ кге $/ \mathrm{cm}^{2}$.

5. Відхилення показників витрати палива та значень ефективності спрацювання РОУ знаходяться у межах від 0,3 до 1,5\%. Похибка розрахунку становить $(0,4+0,2697) \%$.

6. У перспективі необхідна розробка більш потужних і дешевих охолоджуючих реагентів, застосування яких буде безпечно для персоналу. Необхідна також модернізація конструкції 3 метою підвищення iï надійності і захищеності співробітників. У цих напрямках працюють сучасні компанії.

\section{Література}

1. Когенераційні технології в малій енергетиці : монографія / В. А. Маляренко, О. Л. Шубенко, С.Ю. Андрєєв, М. Ю. Бабак, О. В. Сенецький / Харків. нац. ун-т міськ. госп-ва ім. О. М. Бекетова, Ін-т проблем машинобуд. ім. А. М. Підгорного. - Харків : ХНУМГ ім. О. М. Бекетова, 2018. - 454 с.

2. Гічов Ю.О. Теплові електростанції та проблеми перетворення енергії. Частина II : навчальний посібник / Гічов Ю.О. - Дніпро : НМетАУ, 2017. - 59 с.

3. Лухтура Ф. И. О некоторых способах повышения тепловой экономичности и надежности промышленных ТЭЦ [Електронний ресурс] / Ф. И. Лухтура, А. В. Пыжиков, О. А. Хлестова // Вісник Приазовського державного технічного університету. Серія: технічні науки. - 2018. - Вип. 36. - С. 88-100. Режим доступу : http://nbuv.gov.ua/UJRN/vpdty_2018_36_13.

4. Терлецький В. О. Моделювання АCP температури пару за редукційно-охолоджувальною установкою енергоблоку АЕС ВВЕР 1000 МВТ / В. О. Терлецький, Г. П. Лисюк // Вчені записки ТНУ імені В.I. Вернадського. Серія: технічні науки, 2019. - Том 30 (69). № 3 Частина 1. - С. 170-174.

5. Високих Л.В. Підвищення ефективності систем електропостачання за рахунок використання когенераційні установки з турбінною установкою / Л.В. Високих, В.В.Клименко, В.І. Кравченко // Перспективні галузі інформаційно-комп’ютерних систем та мереж, комп'ютерно-інтегровані технології у промисловості, телекомунікаціях, енергетиці та транспорті: Всеукраїнський науково-практичний Інтернет конференція. - Кропивницький, 2019. - URL : http:/www.kntu.kr.ua/doc/zbirnyki/2019/11.pdf.

6. Клименко В.В. Енергозбереження в тепло технологічних процесах та установках : навчальний посібник / Клименко В.В., Кравченко В. І., Телюта Р. В. - Кропивницький : ПП Ексклюзив-Систем, 2020. $219 \mathrm{c.}$

7. Maurer, T. Kältetechnik für Ingenieure / T. Maurer. - GmbH: VDE Verlag, 2016. - 575 p.

8. Li S. X. Dynamic Modeling of Steam Condenser and Design of PI Controller Based on Grey Wolf Optimizer / S. X. Li, J. S. Wang // Mathematical Problems in Engineering. - 2015. - № 2015. - P. 1-9. - DOI $: 10.1155 / 2015 / 120975$.

9. Chepyrniy M. N. Application of steam compression thermal pumping plants for utilization of the discharged heat of steam turbines condensers / M. N. Chepyrniy, N. V. Rezydent. // Scientific works of Vinnytsia national technical university. - 2013. - № 4. - URL: http://nbuv.gov.ua/UJRN/vntue_2013_4_10.

10. Emadi A. Advanced Electric Drive Vehicle / A. Emadi. - Boca Raton, FL: CRC Press, 2015. - 586 p.

11. Takashi M., Shuichi H., Daisuke O., Masahiko T., Jun S. Improvement of thermal environment and reduction of energy consumption for cooling and heating by retrofitting windows. Front. Archit. Res. 2013; 2:1-10.

12. El Mankibi M., Cantin R., Zoubir A. Contribution to the thermal renovation of old buildings: numerical and experimental approach for characterizing a double window. Energy Procedia 2015; 78:2470-2475.

13. Gloriant F., Tittelein P., Joulin A., Lassue S. Study of the performances of a supply-air window for air 
renewal pre-heating. Energy Procedia 2015; 78:525-530.

14. Energy Efficiency Best Practice Guide Steam Systems, Hot Water Systems and Process Heating Systems. URL: https:/genless.govt.nz/assets/Business-Resources/process-heat-best-practice-guide-jan-2011.pdf

\section{References}

1. Koheneratsiini tekhnolohii v malii enerhetytsi : monohrafiia / V. A. Maliarenko, O. L. Shubenko, S.Iu. Andrieiev, M. Yu. Babak, O. V. Senetskyi / Kharkiv. nats. un-t misk. hosp-va im. O. M. Beketova, In-t problem mashynobud. im. A. M. Pidhornoho. - Kharkiv : KhNUMH im. O. M. Beketova, 2018. $-454 \mathrm{~s}$.

2. Hichov Yu.O. Teplovi elektrostantsii ta problemy peretvorennia enerhii. Chastyna II : navchalnyi posibnyk / Hichov Yu.O. Dnipro : NMetAU, 2017. $-59 \mathrm{~s}$.

3. Luhtura F. I. O nekotoryh sposobah povysheniya teplovoj ekonomichnosti i nadezhnosti promyshlennyh TEC [Elektronnij resurs] / F. I. Luhtura, A. V. Pyzhikov, O. A. Hlestova // Visnik Priazovskogo derzhavnogo tehnichnogo universitetu. Seriya: tehnichni nauki. - 2018. Vip. 36. - S. 88-100. - Rezhim dostupu : http://nbuv.gov.ua/UJRN/vpdty 20183613.

4. Terletskyi V. O. Modeliuvannia ASR temperatury paru za reduktsiiño-okholodzhuvalnoiu ustanovkoiu enerhobloku AES VVER 1000 MVT / V. O. Terletskyi, H. P. Lysiuk // Vcheni zapysky TNU imeni V.I. Vernadskoho. Seriia: tekhnichni nauky, 2019. - Tom 30 (69). № 3 Chastyna $1 .-$ S. 170-174.

5. Vysokykh L.V. Pidvyshchennia efektyvnosti system elektropostachannia za rakhunok vykorystannia koheneratsiini ustanovky z turbinnoiu ustanovkoiu / L.V. Vysokykh, V.V.Klymenko, V.I. Kravchenko // Perspektyvni haluzi informatsiino-kompiuternykh system ta merezh, kompiuterno-intehrovani tekhnolohii u promyslovosti, telekomunikatsiiakh, enerhetytsi ta transporti: Vseukrainskyi naukovopraktychnyi Internet konferentsiia. - Kropyvnytskyi, 2019. - URL : http://www.kntu.kr.ua/doc/zbirnyki/2019/11.pdf.

6. Klymenko V.V. Enerhozberezhennia v teplo tekhnolohichnykh protsesakh ta ustanovkakh : navchalnyi posibnyk / Klymenko V.V., Kravchenko V. I., Teliuta R. V. - Kropyvnytskyi : PP Ekskliuzyv-System, 2020. - 219 s.

7. Maurer, T. Kältetechnik für Ingenieure / T. Maurer. - GmbH: VDE Verlag, 2016. - 575 p

8. Li S. X. Dynamic Modeling of Steam Condenser and Design of PI Controller Based on Grey Wolf Optimizer/ S. X. Li, J. S. Wang // Mathematical Problems in Engineering. - 2015. - № 2015. - R. 1-9. - DOI :10.1155/2015/120975.

9. Chepyrniy M. N. Application of steam compression thermal pumping plants for utilization of the discharged heat of steam turbines condensers / M. N. Chepyrniy, N. V. Rezydent. // Scientific works of Vinnytsia national technical university. - 2013. - № 4. - URL: http://nbuv.gov.ua/UJRN/vntue 2013410.

10. Emadi A. Advanced Electric Drive Vehicle / A. Emadi. - Boca Raton, FL: CRC Press, 2015. - 586 p.

11. Takashi M., Shuichi H., Daisuke O., Masahiko T., Jun S. Improvement of thermal environment and reduction of energy consumption for cooling and heating by retrofitting windows. Front. Archit. Res. 2013; 2:1-10.

12. El Mankibi M., Cantin R., Zoubir A. Contribution to the thermal renovation of old buildings: numerical and experimental approach for characterizing a double window. Energy Procedia 2015; 78:2470-2475.

13. Gloriant F., Tittelein P., Joulin A., Lassue S. Study of the performances of a supply-air window for air renewal pre-heating. Energy Procedia 2015; 78:525-530.

14. Energy Efficiency Best Practice Guide Steam Systems, Hot Water Systems and Process Heating Systems. URL: https://genless.govt.nz/assets/Business-Resources/process-heat-best-practice-guide-jan-2011.pdf

О.Я. ВОЛОШАНЮК

О.В. НЕЧИПОРЕНКО
Orcid-id: 0000/0002/0484/9111

Надійшла/Paper received : 20.04.2021 p. Надрукована/Printed : 07.06.2021 p. 